\title{
Marinobacter Dominates the Bacterial Community of the Ostreococcus tauri Phycosphere in Culture
}

\author{
Josselin Lupette ${ }^{1,2,3}$, Raphaël Lami ${ }^{4,5}$, Marc Krasovec ${ }^{1,2}$, Nigel Grimsley 1,2, \\ Hervé Moreau 1,2, Gwenaël Piganeau ${ }^{1,2}$ and Sophie Sanchez-Ferandin ${ }^{1,2 *}$
}

${ }_{1}^{1}$ Sorbonne Universités, Université Pierre et Marie Curie Paris 06, UMR 7232 Biologie Intégrative des Organismes Marins, Observatoire Océanologique, Banyuls-sur-Mer, France, ${ }^{2}$ Centre National de la Recherche Scientifique, UMR 7232 Biologie Intégrative des Organismes Marins, Observatoire Océanologique, Banyuls-sur-Mer, France, ${ }^{3}$ CEA/CNRS/INRA/Université Grenoble Alpes, UMR 5168 Laboratoire Physiologie Cellulaire Végétale, Grenoble, France, ${ }^{4}$ Sorbonne Universités, Université Pierre et Marie Curie Paris 06, USR 3579 Laboratoire de Biodiversité et Biotechnologies Microbiennes, Observatoire Océanologique, Banyuls-sur-Mer, France, ${ }^{5}$ Centre National de la Recherche Scientifique, USR 3579 Laboratoire de Biodiversité et Biotechnologies Microbiennes, Observatoire Océanologique, Banyuls-sur-Mer, France

\section{OPEN ACCESS}

Edited by:

Michael Thomas-Poulsen, University of Copenhagen, Denmark

Reviewed by:

Tony Gutierrez,

Heriot-Watt University, Scotland

Garret Suen,

University of Wisconsin-Madison,

USA

${ }^{*}$ Correspondence:

Sophie Sanchez-Ferandin sophie.sanchez-ferandin@obs-

banyuls.fr

Specialty section:

This article was submitted to

Microbial Symbioses,

a section of the journal

Frontiers in Microbiology

Received: 25 May 2016

Accepted: 26 August 2016 Published: 07 September 2016

Citation:

Lupette J, Lami R, Krasovec M, Grimsley N, Moreau H, Piganeau G

and Sanchez-Ferandin S (2016) Marinobacter Dominates the Bacterial Community of the Ostreococcus tauri

Phycosphere in Culture.

Front. Microbiol. 7:1414.

doi: 10.3389/fmicb.2016.01414
Microalgal-bacterial interactions are commonly found in marine environments and are well known in diatom cultures maintained in laboratory. These interactions also exert strong effects on bacterial and algal diversity in the oceans. Small green eukaryote algae of the class Mamiellophyceae (Chlorophyta) are ubiquitous and some species, such as Ostreococcus spp., are particularly important in Mediterranean coastal lagoons, and are observed as dominant species during phytoplankton blooms in open sea. Despite this, little is known about the diversity of bacteria that might facilitate or hinder O. tauri growth. We show, using rDNA 165 sequences, that the bacterial community found in O. tauri RCC4221 laboratory cultures is dominated by $\gamma$-proteobacteria from the Marinobacter genus, regardless of the growth phase of $O$. tauri RCC4221, the photoperiod used, or the nutrient conditions (limited in nitrogen or phosphorous) tested. Several strains of Marinobacter algicola were detected, all closely related to strains found in association with taxonomically distinct organisms, particularly with dinoflagellates and coccolithophorids. These sequences were more distantly related to $M$. adhaerens, M. aquaeoli and bacteria usually associated to euglenoids. This is the first time, to our knowledge, that distinct Marinobacter strains have been found to be associated with a green alga in culture.

Keywords: Ostreococcus tauri, Marinobacter sp., picoalgae, bacteria, interactions, phytoplankton

\section{INTRODUCTION}

Phytoplankton, together with viruses, bacteria, and micrograzers constitute different communities of species which all play fundamental roles in the functioning of microbial food web (Buchan et al., 2014). Phytoplankton and bacterial communities are closely linked in coastal marine environments (Fuhrman et al., 1980; Rooney-Varga et al., 2005; Amin et al., 2015) and bacterial-algal interactions play a major role in determining bacterial and algal diversity in the ocean (Schäfer et al., 2002). Detailed knowledge of these interactions is thus crucial for understanding marine ecosystems. 
Phytoplankton exudates can be important substrates for bacteria, especially in early phytoplankton bloom conditions (Fouilland et al., 2013) although other carbon sources might also be important for bacterial growth (Fouilland and Mostajir, 2010). In turn, some bacteria are known to inhibit or promote microalgal growth (Cole, 1982; Fukami et al., 1997; de-Bashan et al., 2004). The volume of water closely surrounding algal cells in which many metabolic exchanges may occur, is called the phycosphere (Bell and Mitchell, 1972). It is analogous to the rhizosphere in soils and it has direct implications for nutrient fluxes to and from algal cells (Amin et al., 2012b). In this niche, bacteria can live freely around microalgae and interact through metabolic fluxes via the environmental medium, or they may be more closely associated with the cells, such as epiphytic or endophytic bacteria. Epiphytic bacteria adhere to the microalgal surface (Bell and Mitchell, 1972; Shapiro et al., 1998) with a tight functional association (Middelboe et al., 1995; Smith et al., 1995; Grossart et al., 2005). Endophytic bacteria are able to develop inside microalgal cells and have been seen in Chlorophyta (Kawafune et al., 2012). Both commensalism and/or competition for micronutrients may occur between phytoplankton and bacteria (Bratbak and Thingstad, 1985; Amin et al., 2012a). Bacteria might positively (stimulation) or negatively (inhibition, alteration of physiology, death) influence phytoplankton dynamics. As examples, stimulation of phytoplankton growth by bacteria can occur via the production of vitamins (Haines and Guillard, 1974; Kurata, 1986; Croft et al., 2005; Kuo and Lin, 2013), siderophores (Martinez et al., 2000, 2003; Amin et al., 2009) or phytohormones (de-Bashan et al., 2008) like auxin (Gonzalez and Bashan, 2000). In contrast, bacteria can even kill the algae by the secretion of algicidal compounds (Mayali and Azam, 2004).

Some studies demonstrated the presence of specific bacterial communities associated with algal blooms in marine environments (Gonzalez et al., 2000; Buchan et al., 2014). In axenic (i.e., exempt of bacteria) microalgal monocultures, microalgal growth may be unstable and prone to perturbation (Kazamia et al., 2014), highlighting again the importance of microalgalbacterial interactions, not only in natural environments but also in laboratory culture conditions. However, except for some species (Alavi et al., 2001; Green et al., 2004, 2015; Jasti et al., 2005), particularly diatoms (Grossart et al., 2005; Sapp et al., 2007a,b; Eigemann et al., 2013; Amin et al., 2015; Mishamandani et al., 2016), the bacterial diversity associated with microalgae species is still poorly known. Small green algae belonging to the order Mamiellales are ubiquitous in the world oceans including the Arctic zone (de Vargas et al., 2015), and are of prime importance in the ecology of Mediterranean coastal lagoons. Among this group, the smallest free-living eukaryotic cell Ostreococcus tauri was discovered in the Mediterranean lagoon Thau 20 years ago (Courties et al., 1994), and can be observed as a dominant species during phytoplanktonic blooms in coastal seas (O'Kelly et al., 2003). In such lagoons or coastal regions where limnic and oceanic waters meet, the environment is more variable than in open sea, strongly influencing bacterial diversity (Glöckner et al., 1999; Herlemann et al., 2011; Bižić-Ionescu et al., 2015). O. tauri is also being used as a model organism for studying diverse environmental problems like sensitivity to herbicides (Sanchez-Ferandin et al., 2013) or tolerance to polluants like arsenic (Zhang et al., 2013). Despite the wealth of genomic data available for this species (Derelle et al., 2006; Blanc-Mathieu et al., 2014), the bacterial community associated with the $O$. tauri phycosphere is poorly understood, and the nature of the interactions between $O$. tauri and bacteria remains an open question (Abby et al., 2014).

Here, we focus on the nature and dynamics of the microbiome of $O$. tauri RCC4221 across a large range of culture conditions. Surprisingly, we provide evidence that bacteria from one single genus, Marinobacter ( $\gamma$-proteobacteria, order Alteromonadales) is largely predominant across culture conditions.

\section{MATERIALS AND METHODS}

\section{Ostreococcus tauri RCC4221 Culture in Different Conditions}

Ostreococcus tauri strain RCC4221 was isolated in 1994 from the North-West Mediterranean Thau lagoon (Courties et al., 1994) and maintained in the laboratory (cultures and cryopreservation). The $O$. tauri strain was grown in liquid medium in aerated flasks (Sarstedt), in growth chambers at $20 \pm 1^{\circ} \mathrm{C}$ and white light at around $100 \mu \mathrm{mol}$ photons. $\mathrm{m}^{-2} \cdot \mathrm{sec}^{-1}$ using three photoperiods (LD 08:16; LD 12:12; and LD 14:10). Two culture media were prepared, one with natural sea water, L1-MOLA (Guillard and Hargraves, 1993) and one with artificial sea water, F/2-ESAW (Harrison et al., 1980). Both L1-MOLA and $\mathrm{F} / 2$-ESAW were produced by adding nitrogen $\left(\mathrm{NaNO}_{3}\right)$, phosphorus $\left(\mathrm{NaH}_{2} \mathrm{PO}_{4}\right)$ and vitamins $(\mathrm{B} 1, \mathrm{~B} 12$, and $\mathrm{H})$ but at different concentrations (Supplementary Table S1). Only L1-MOLA was prepared from seawater, collected from $20 \mathrm{~m}$ below sea level at the MOLA station and kept several weeks in the dark before use. The seawater was filtered through $0.22 \mu \mathrm{m}$ and autoclaved. For nutrient limitation experiments, four conditions were tested: L1-MOLA, F/2-ESAW, F/2-ESAW $50 \% \mathrm{~N}$ (half nitrogen concentration), and F/2-ESAW 10\%P (one tenth phosphorous concentration) (see Supplementary Table S1 for the detailed composition of each medium used in this study). For each tested condition, cultures were prepared in triplicates. Considering all of the culture experimentations (three photoperiods and four culture media conditions mentioned above), a total of 12 different conditions were used in triplicate, thus 36 different flasks maintained in incubators. Half a milliliter of each culture was collected daily during 35 days and then fixed $10 \mathrm{~min}$ at room temperature in the dark with glutaraldehyde (Sigma \#G5882 - final concentration: 1\%) before frozen in liquid nitrogen and stored at $-80^{\circ} \mathrm{C}$.

\section{Cell Concentrations and Growth Rates}

Cell concentrations were determined using flow cytometry (FACSCantoII $^{\mathrm{TM}}$, Becton Dickinson, San Jose, CA, USA). O. tauri cells were detected using the red fluorescence emission (FL3) of chlorophyll pigments. For enumeration of bacteria, nucleic acids were labeled with SYBR ${ }^{\circledR}$ Green I (Lonza, \# 50512) and were detected by green fluorescence (FL1) (Marie et al., 1997). Two kinds of bacteria were distinguished: HNA (High 
apparent Nucleic Acid content) and LNA (Low apparent Nucleic Acid content) bacteria (Gasol et al., 1999). Growth rates $\left(\mu_{\max }\right)$ were determined from cell concentrations measured at different times with the following equation (Levasseur et al., 1993):

$$
\mu_{\max }=\ln \left(N_{2} / N_{1}\right) /\left(t_{2}-t_{1}\right)
$$

(where $N_{1}, N_{2}$, are cell abundances in the exponential phase at times $t_{1}$ and $t_{2}$ ).

\section{Endpoint Dilutions of O. tauri RCC4221 for Isolation of Associated Bacteria}

An O. tauri RCC4221 culture was diluted serially to permit isolation of single microalgal cells in individual culture wells [by "extinction dilution" or "endpoint dilution," see for example (Taylor, 1962)], reducing also the density of bacteria. Sixteen independent lines obtained in this way from a single cell were maintained similarly by enumeration and dilution through 27 serial single-cell endpoint dilutions (about 500 cell divisions over the 54 weeks of culture). All of the cell lines were grown in L1 medium in 24 well plates with single-cell endpoint dilutions at every 14-day sub-culturing step (Krasovec et al., 2016) (Table 1). Each line was then screened on marine agar plates to isolate bacterial colonies and identify their diversity by PCR. The W18 bacterial forward (5'-GNTACCTTGTTACGACTT-3') and W02 universal reverse (5'-GAGTTTGATCMTGGCTCAG-3') primers were used (Godon et al., 1997). PCR were run with the Kapa Extra HS mix (CliniSciences) and standard amplification (35 cycles of $15 \mathrm{~s}$ at $95^{\circ} \mathrm{C}, 15 \mathrm{~s}$ at $50^{\circ} \mathrm{C}$ and $1 \mathrm{~min} 20 \mathrm{~s}$ at $72^{\circ} \mathrm{C}$ ). Amplified DNAs were sequenced with Sanger method by Cogenics (Takeley, Essex, UK) and Bio2Mar platform (Banyulssur-mer, France).

\section{Identification of Cultivable and Total Bacteria in O. tauri RCC4221 Standard and Limiting Nutrient Conditions}

For each tested culture condition, aliquots of $100 \mu \mathrm{L}$ of $O$. tauri cultures were spread onto L1-MOLA solid medium plates every 5 days. After 2 days of incubation in the same conditions as the ones used for the incubation of cells in liquid medium (see the section of Materials and Methods), DNA samples extracted from four morphologically identical colonies per condition were sequenced for a total of 12 conditions (384 sequences; Table 1). For total bacterial diversity identification, an aliquot of $100 \mu \mathrm{L}$ of culture was taken each day during the growth of O. tauri
RCC4221, fixed in glutaraldehyde 1\% (Sigma), frozen in liquid nitrogen, and stored at $-80^{\circ} \mathrm{C}$. Then, in order to follow bacterial diversity at specific times along $O$. tauri growth, aliquots were pooled following the four different O. tauri RCC4221 growth phases: latency (LAT), exponential (EXP), stationary (STA) and decline (DEC) phases. Only samples corresponding to the LD 14:10 condition (for which the whole O. tauri growth from LAT to DEC phases was observed) were extracted for subsequent ribosomal 16S DNA sequencing (Table 1).

\section{Statistical Analyses and Graphical Representations}

Statistical analyses were performed with $\mathrm{R}$ version 3.2.0 software $^{1}$. $t$-tests were done on paired samples by permutation (t.paired.perm.R function) ${ }^{2}$ were performed. Graphical views from $\mathrm{R}$ and Excel were saved in pdf.

\section{High Throughput Sequencing Data Analysis}

Sixteen different conditions were analyzed, using four samples (corresponding to the four $O$. tauri different growth phases: latent period, exponential growth, stationary phase, decline) for each medium. The samples were named OtL1LAT, OtL1EXP, OtL1STA, and OtL1DEC for L1 culture medium; Otf2LAT, Ot f2EXP, Ot f2STA, and Ot f2DEC for f/2 culture medium; OtPLAT, OtPEXP, OtPSTA, and OtPDEC for F/2 (50\% [P]); and OtNLAT, OtNEXP, OtNSTA, and OtNDEC for F/2 (10\% $[\mathrm{N}])$. For each condition, DNA extraction was performed by using the modified CTAB method (Winnepenninckx et al., 1993). Total microbial 16S rDNA diversity of each of these 16 DNA samples was estimated by Illumina, $2 \times 300$ bp PE sequencing 20,000 PCR-amplified sequences (MrDNA, Molecular Research Laboratory, 503 Clovis Road, Shallowater, TX 79363 USA). The 16S rRNA gene V4 variable region PCR primers 515/806 with barcode on the forward primer were used in a 28 cycles PCR using the HotStarTaq Plus Master Mix Kit (Qiagen, USA) under the following conditions: $94^{\circ} \mathrm{C}$ for $3 \mathrm{~min}$, followed by 28 cycles of $94^{\circ} \mathrm{C}$ for $30 \mathrm{~s}, 53^{\circ} \mathrm{C}$ for $40 \mathrm{~s}$ and $72^{\circ} \mathrm{C}$ for $1 \mathrm{~min}$, after which a final elongation step at $72^{\circ} \mathrm{C}$ for 5 min was performed. After amplification, PCR products were checked in $2 \%$ agarose gel to determine the success of amplification and the relative intensity of bands. Sixteen samples were pooled

${ }^{1}$ http://www.R-project.org

${ }^{2}$ http://adn.biol.umontreal.ca/ numericalecology/Rcode/

TABLE 1 | Summary of the different experimental conditions.

\begin{tabular}{lllll}
\hline Photoperiod & Experimental conditions & Number of O. tauri cultures & $\begin{array}{l}\text { Samples for Sanger } \\
\text { sequencing }\end{array}$ & $\begin{array}{l}\text { Samples for } \\
\text { Illumina } \\
\text { sequencing }\end{array}$ \\
\hline 08:16 & Serial endpoint dilutions cultures & 16 & 48 & None \\
& L1-MOLA & Cultures in triplicates & 384 & 16 \\
08:16 & F/2-ESAW & & for all photoperiods and all & photoperiod 14:10 \\
$12: 12$ & F/2-ESAW 50\%N & & experimental conditions & LAT, EXP, STA, DEC \\
$14: 10$ & F/2-ESAW 10\%P & & & for all experimental \\
& & & & conditions
\end{tabular}


together in equal proportions based on their molecular weight and DNA concentrations. Pooled samples were purified using calibrated Ampure XP beads. Then the pooled and purified PCR products were used to prepare the Illumina DNA library. Sequencing was performed at MR DNA on a MiSeq following the manufacturer's guidelines. Sequence data were processed using MR DNA analysis pipeline ${ }^{3}$ and analyzed using QIIME software (Quantitative Insights Into Microbial Ecology) ${ }^{4}$ (Caporaso et al., 2010). In summary, sequences were joined, depleted of barcodes then sequences $<150$ bp removed, and sequences with ambiguous base calls removed. A 97\% cut-off for sequence identity was used for classification into OTUs. The sequences obtained were dominated by $O$. tauri mitochondrial sequences $(>85 \%)$ and the analysis was conducted after eliminating these sequences, leaving 97362 bacterial sequences of interest spread among the 16 different conditions (roughly 6085 bacterial sequences per condition). Sequences were submitted to GenBank with the project reference (BioProject ID) PRJNA328274.

\section{Alignments and Phylogenetic Reconstructions}

Among the 97362 total sequences obtained, 88179 (90.6\%) were assigned to Marinobacter spp., clustered at $97 \%$ identity threshold inside six distinct OTUs after eliminating sequencing errors (instead of 799 initially obtained comprising 617 OTUs with one sequence and 176 OTUs with less than 200 sequences). The majority of Marinobacter sequences (95.3\%) grouped inside one unique OTU (84817 sequences in OTU_7771). Among the remaining sequences, $6 \%$ (5821 sequences) were assigned to the Hyphomonas genus, and clustered in two main OTUs. The majority of Hyphomonas sequences (96.4\%) grouped inside one unique OTU (5609 sequences in OTU_6113). The alignment of OTU sequences with annotated NCBI 16S rDNA sequences was performed using Clustal W (Thompson et al., 1994) implemented in MEGA 6.1 software (Tamura et al., 2013). The sequence alignment was then adjusted manually. The best evolutionary model was chosen using MEGA 6.1 software and resulted in Kimura two parameters with a Gamma correction. Two phylogenetic trees were constructed following this model by Neighbor-Joining (NJ) and Maximum Likelihood (ML) approaches using 1000 bootstrap replicates. Gram positive bacteria (Staphylococcus) and Gram negative $\delta$-proteobacteria (Geobacter) were used as outgroups. Given that the two topologies obtained from the two phylogenetical methods were highly similar, only the NJ phylogenetic tree was shown with the bootstraps values resulting from each method.

\section{RESULTS}

\section{Abundance and Dynamics of Bacteria in the O. tauri Phycosphere}

Globally, the highest O. tauri RCC4221 maximal growth rates in exponential phase were observed for cells cultivated in

${ }^{3}$ www.mrdnalab.com

${ }^{4}$ http://qiime.org/
L1-MOLA and F/2-ESAW media at LD 12:12 light cycle condition (Figure 1). Interestingly, maximal growth rate appears more important in $\mathrm{F} / 2$-ESAW medium than in $\mathrm{F} / 2$-ESAW $10 \% \mathrm{P}$ at this LD 12:12 photoperiod ( $p$-value < 0.05) (Figure 1). In the other photoperiods, no significant difference was observed between the distinct F/2-ESAW media. We can also observe a decrease in O. tauri maximal growth rate in L1-MOLA compared to the one of cells cultivated in F/2-ESAW at LD 08:16 light cycle condition (certainly because of a longer exponential growth phase in L1-MOLA than in F/2-ESAW with minimal light) ( $p$-value < 0.005) (Figure 1). After 20 days of growth, the highest $O$. tauri cell abundances were observed in L1 MOLA medium whatever the photoperiodic conditions (Figure 2). Whatever the culture medium or the photoperiodic condition, different phases of $O$. tauri growth can be identified and are described in Figure 2. However, depending upon the different experimental approaches used, these phases can exhibit various durations (Figure 2). Globally, the cell concentration reached in the different culture conditions is the lowest in ESAW $10 \% \mathrm{P}$ whatever the other experimental conditions (Figure 2). The relative abundance of total bacteria in O. tauri RCC4221 cultures was measured over 35 days in the 12 different conditions (Figure 3). HNA (High content DNA) and LNA (Low content DNA) bacteria (Gasol et al., 1999) were observed in the different culture conditions (Figure 3). They were considered as dominant when log (HNA bacteria and LNA bacteria/O. tauri) ratios $>1$ (Figure 3). Overall, the lowest bacterial abundances were observed when the cultures were grown in L1 MOLA medium (Figure 3) and the highest proportions of $O$. tauri cells relatively to bacteria were observed during the exponential growth phase (approximately

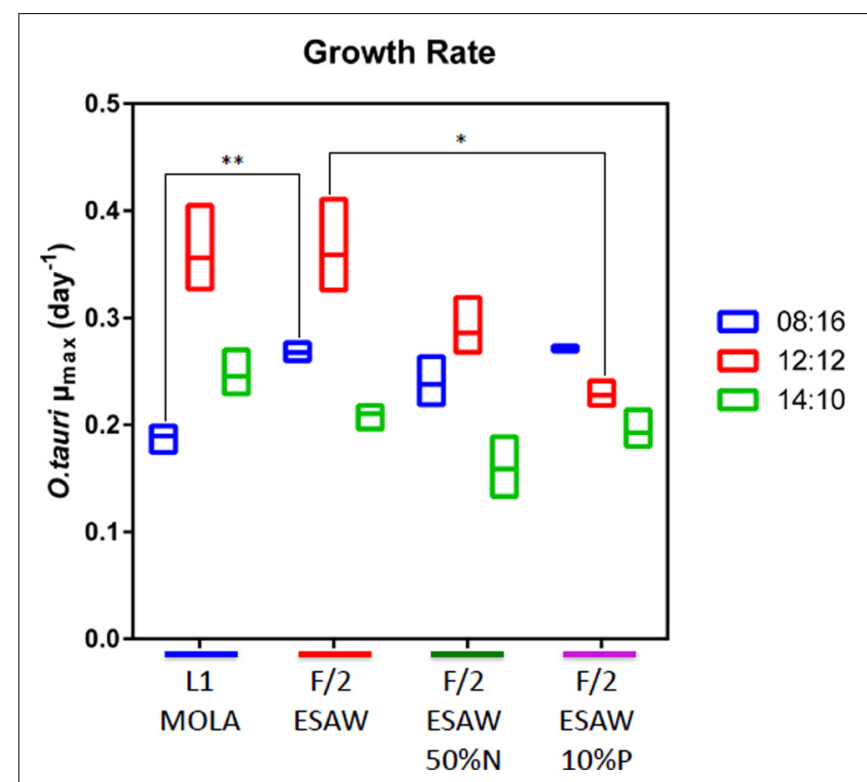

FIGURE 1 | O. tauri RCC4221 growth rates comparison in four different media and three different photoperiods. Media: L1-MOLA, F/2-ESAW (complete media), F/2-ESAW 50\%N (nitrogen concentration divided per 2) and F/2-ESAW 10\%P (phosphorus concentration divided per 10).

Photoperiods: LD 12:12, LD 08:16, LD 14:10. ${ }^{*} p<0.05$ and ${ }^{* *} p<0.005$. 

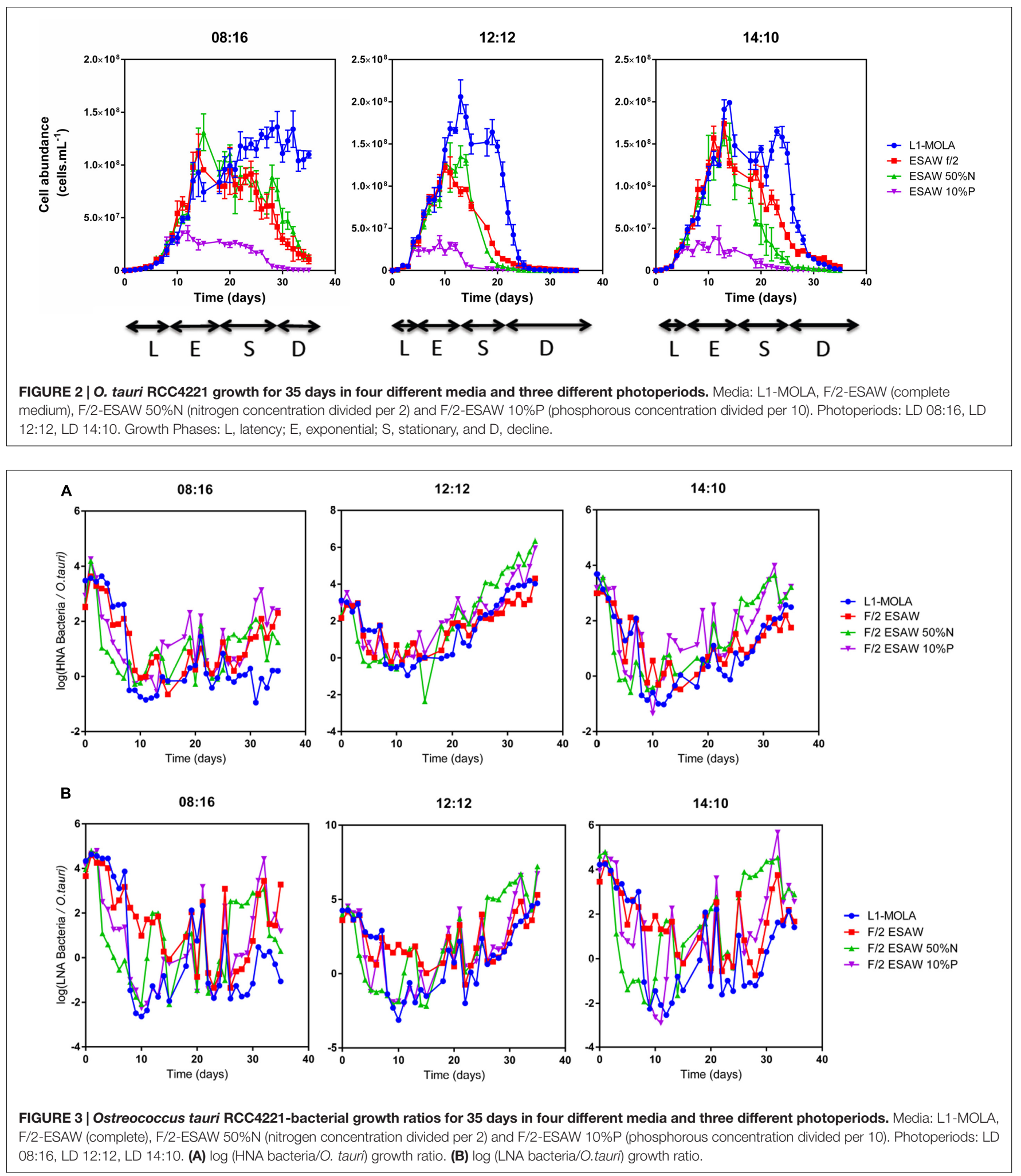

after 10 days growth) (Figures 2 and 3). However, whatever the culture conditions, the highest densities of HNA and LNA bacteria were present in O. tauri RCC4221 culture during latency (from 0 to 8 days approximately) and decline (starting from
25 days) phases (Figures 3A,B). Since some bacteria may be adhering to algal cells, these figures probably underestimate the actual number of bacteria present. The latency and decline phases are advantageous for the development of LNA bacteria while 
the exponential phase is more suitable for the development of HNA bacteria (except in F2-ESAW medium). A majority of LNA bacteria [with log (LNA bacteria/O. tauri) ratio around 2] are simultaneously present with microalgal cells in exponential phase in F2-ESAW medium (Figure 3B). The proportion of LNA bacteria increases when cultivated in F/2-ESAW 50\%N and F/2ESAW $10 \% \mathrm{P}$ media compared to L1-MOLA medium and are predominant in $\mathrm{F} / 2$-ESAW medium whatever the photoperiod condition (Figure 3B). In contrast, the development of HNA bacteria was higher in nitrogen-limited medium (except in LD 08:16 photoperiodic condition) and in phosphorus-limited medium in a period corresponding to the stationary phase (from 15 to 25 days approximately) in all tested photoperiodic conditions (Figure 3A) while LNA bacteria seem predominant starting from 25 days (Figure 3B).

\section{Diversity of Culturable versus Total Bacteria during O. tauri RCC4221 Growth}

Whatever the culture conditions used in the culture-dependent approach, bacteria from the $\gamma$-proteobacteria group were largely dominant. From the $16 \mathrm{O}$. tauri independent lines that were endpoint diluted 27 times through serial subcultures, all the bacteria isolated on either solid Marine Agar or L1 media exhibited one unique 16S sequence ("Marinobacter sp. strain 1," Figure 4), closely related to the Marinobacter genus ( $\gamma$-proteobacteria, order Alteromonadales) (Table 2; Figure 4). The full-length $16 \mathrm{~S}$ sequence showed $98 \%$ identity to the Marinobacter algicola and Marinobacter sp. DS1930-III sequences. Bacteria isolated on L1 solid medium during the 35 days of O. tauri RCC4221 growth in the different culture conditions also exhibited the same full-length $16 \mathrm{~S}$ sequence with 98\% identity to the Marinobacter algicola species in $95.3 \%$ of the bacteria identified (Table 2). Other $\gamma$-, $\beta$-, and $\alpha$-culturable proteobacteria were also detected in the different cultures, albeit found much less frequently. One sequence belonging to Pseudomonas ( $\gamma$-proteobacteria) was found with $O$. tauri cultivated in L1-MOLA medium after 15 days-growth under LD 12:12 photoperiod (Figure 4); one sequence belonging to Hyphomonas ( $\alpha$-proteobacteria) was found with $O$. tauri cultivated in L1-MOLA medium at the beginning of the growth under LD 08:16 photoperiod (Figure 4); one sequence belonging to Massilia genus ( $\beta$-proteobacteria) was found with $O$. tauri cultivated in F/2-ESAW medium at the beginning of the growth under LD 14:10 photoperiod (Figure 4); and one Gram-positive bacteria sequence, from the Staphylococcus genus was found, possibly a contaminant from handling of cultures.

The total bacterial diversity in O. tauri RCC4221 cultures was investigated by Illumina sequencing at distinct growth phases (latency, exponential, stationary, and decline phases) during the 35 days' growth in 14:10 light-dark cycles. Globally, the total diversity observed was entirely congruent with our results using a culture-dependent approach showing a large majority of Marinobacter spp. (Table 2). More precisely, in spite of the relatively small $16 \mathrm{~S}$ sequence length available, the total diversity analysis provided evidence for diverse Marinobacter strains (Figure 4). These partial sequences are clearly closely related to a group comprising free-living $M$. salsuginis, M. algicola, $M$. MOLA20 and diverse Marinobacter spp. found associated with different microalgae $\left(\mathrm{BP}_{\mathrm{NJ}}=90, \mathrm{BP}_{\mathrm{ML}}=85\right.$, Figure 4). More precisely, they exhibit a close relationship to the $M$. algicola clade $\left(\mathrm{BP}_{\mathrm{NJ}}=65, \mathrm{BP}_{\mathrm{ML}}=56\right.$, Figure 4). In addition to the OTU 7771 (84817 sequences) found as $99 \%$ identical to the previously identified culturable Marinobacter strain (Marinobacter sp. strain 1, Figure 4), several variants were found from the total diversity analysis (the following percentages of identity are calculated from the partial sequences used in the final alignment): OTU 242 (704 sequences), that is $96.7 \%$ identical to OTU 7771, OTU 5245 (512 sequences), 96\% identical to OTU 7771, OTU 1418 (239 sequences), 96.7\% identical to OTU 7771, OTU 11824 (211 sequences), 96.7\% identical to OTU 7771 (Figure 4). All of the Hyphomonas sequences obtained from Illumina sequencing were closely related to $H$. johnsonii sequences, with strong bootstrap support $\left(\mathrm{BP}_{\mathrm{NJ}}=87\right)$ in the Hyphomonas clade $\left(\mathrm{BP}_{\mathrm{NJ}}=99\right.$, $\mathrm{BP}_{\mathrm{ML}}=98$ ) of $\alpha$-proteobacteria (Figure 4).

Marinobacter was by far the most frequently found genus and Marinobacter sequences were present at all stages and conditions during the growth of O. tauri RCC4221 (Figure 5). In addition to $\gamma$-proteobacteria, sequences from $\alpha$-proteobacteria (mainly Hyphomonas species) were recovered (Figure 5) at a low percentage in the culture-dependent approach $(0.3 \%)$, but at a higher frequency by Illumina sequencing (6\%). Whatever the culture conditions, the Marinobacter genus always predominated (90.6\%, Table 2). The highest proportion of Hyphomonas sequences was observed during exponential, stationary and decline phases, particularly in L1, F/2 and N-limited media conditions (Figure 5).

\section{DISCUSSION}

\section{Marinobacter ( $\gamma$-Proteobacteria) Was the Most Prevalent Genus Across a Wide Range of Culture Conditions}

Globally, the analysis of diversity using Illumina sequencing on total community was entirely congruent with diversity inferred with a culture-dependent approach. Strikingly, all 16 O. tauri RCC4221 cultures regularly submitted to serial endpoint dilutions to one single cell per $\mathrm{ml}$ contained only sequences from the Marinobacter genus. These observations strongly suggest that these bacteria are required for O. tauri RCC42221 growth in our culture conditions but we cannot exclude the opportunistic presence of Marinobacter, given the enriched cultures media used and the possible use by bacteria of exudates secreted by microalgae, as shown in other bacteriaphytoplankton interactions (Fouilland et al., 2013). Interestingly, in our study, several distinct Marinobacter strains were present simultaneously and systematically throughout the growth of the O. tauri RCC4221 strain, whatever the conditions tested, as shown by high-throughput Illumina sequencing of PCRamplified $16 \mathrm{~S}$ ribosomal gene sequences directly from the algal culture, with no separate bacterial culture step, revealing an unsuspected genetic diversity. This suggests that in general 

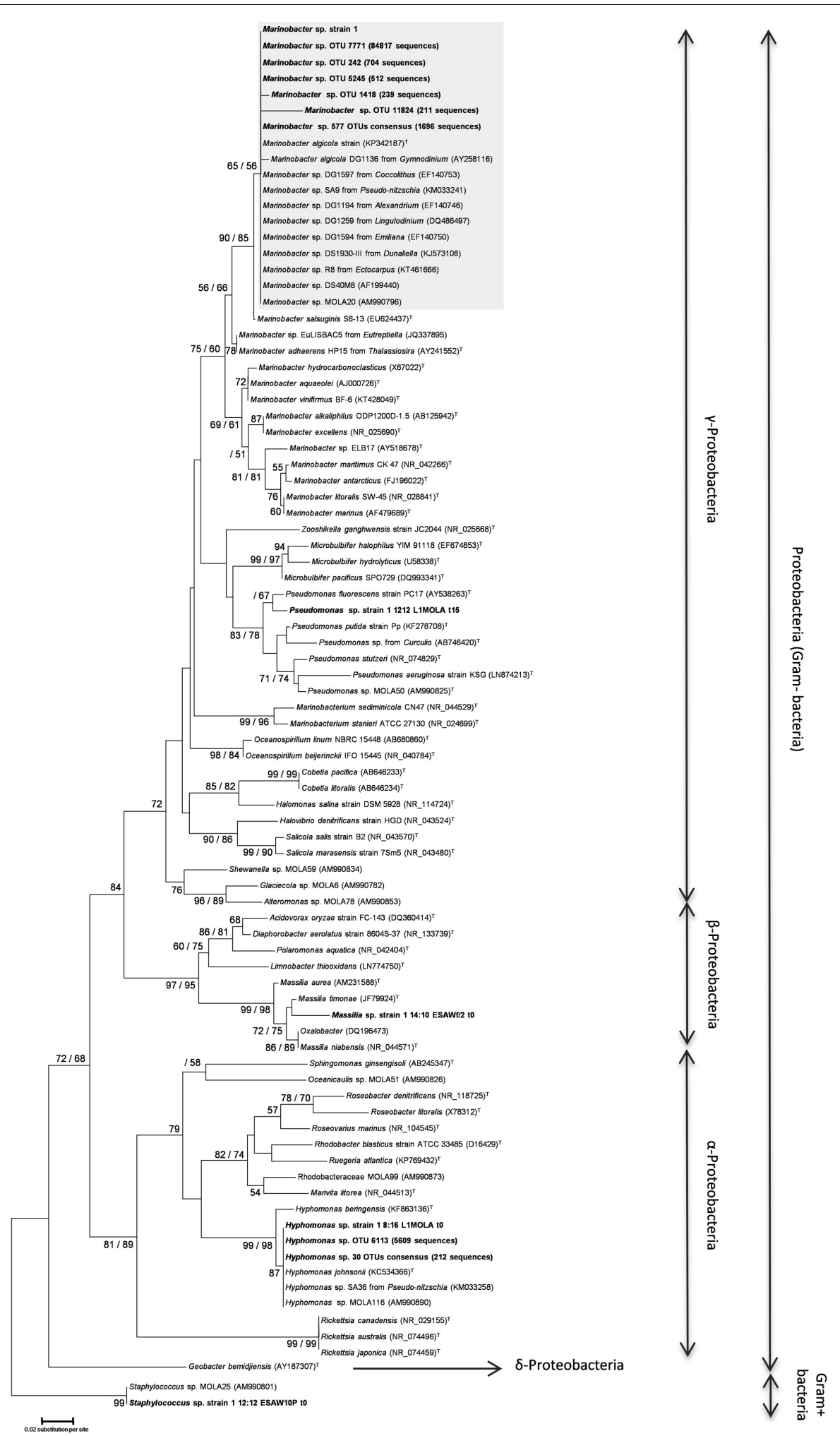

FIGURE 4 | Neighbor-Joining phylogenetic tree obtained from partial 16S DNA alignment of bacterial sequences obtained from this study and from GenBank. Numbers reported on the nodes of the tree are the bootstrap values (BP) obtained from NJ and ML methods (BP $\left.P_{N J} / B_{M L}\right)$. Only those superior to 50 are reported. The gray box shows Marinobacter sequences affiliated to M. algicola species from our phylogenetic reconstructions. The name "Marinobacter sp. strain 1 " refers to the Sanger-sequencing of Marinobacter obtained from the culture-based approach. Sequences obtained in this study were submitted to GenBank with the project reference (BioProject ID) PRJNA328274. 
TABLE 2 | Numbers of 16S ribosomal RNA sequences analyzed.

\begin{tabular}{|c|c|c|c|c|c|}
\hline Approach & $\begin{array}{l}\text { Experimental } \\
\text { conditions }\end{array}$ & $\begin{array}{c}\text { Number of bacterial } \\
\text { sequences }\end{array}$ & $\begin{array}{l}16 S \text { rDNA } \\
\text { gene }\end{array}$ & $\begin{array}{c}\text { Percentage of } \\
\text { Marinobacter sequences }\end{array}$ & $\begin{array}{c}\text { Percentage of } \\
\text { Hyphomonas sequences }\end{array}$ \\
\hline \multirow[t]{2}{*}{$\begin{array}{l}\text { Culture-dependant } \\
\text { (solid medium) }\end{array}$} & $\begin{array}{l}\text { Serial endpoint dilutions } \\
\text { cultures }\end{array}$ & 48 & $\begin{array}{l}\text { Complete } \\
\text { (1455 bp) }\end{array}$ & $100 \%$ & - \\
\hline & $\begin{array}{l}\text { L1-MOLA/F/2- } \\
\text { ESAW/F/2-ESAW } \\
\text { 50\%N/F/2-ESAW 10\%P }\end{array}$ & 384 & $\begin{array}{l}\text { Complete } \\
\text { (1455 bp) }\end{array}$ & $95.3 \%$ & $0.3 \%$ \\
\hline $\begin{array}{l}\text { Culture-independent } \\
\text { (Illumina) }\end{array}$ & $\begin{array}{l}\text { L1-MOLA/F/2- } \\
\text { ESAW/F/2-ESAW } \\
\text { 50\%N/F/2-ESAW 10\%P }\end{array}$ & 97362 & Partial (270 bp) & $90.6 \%$ & $6 \%$ \\
\hline
\end{tabular}

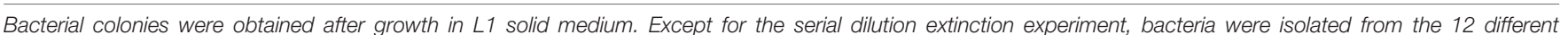

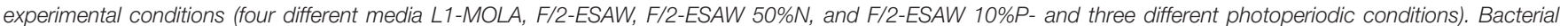

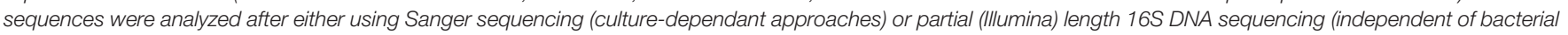
culture).

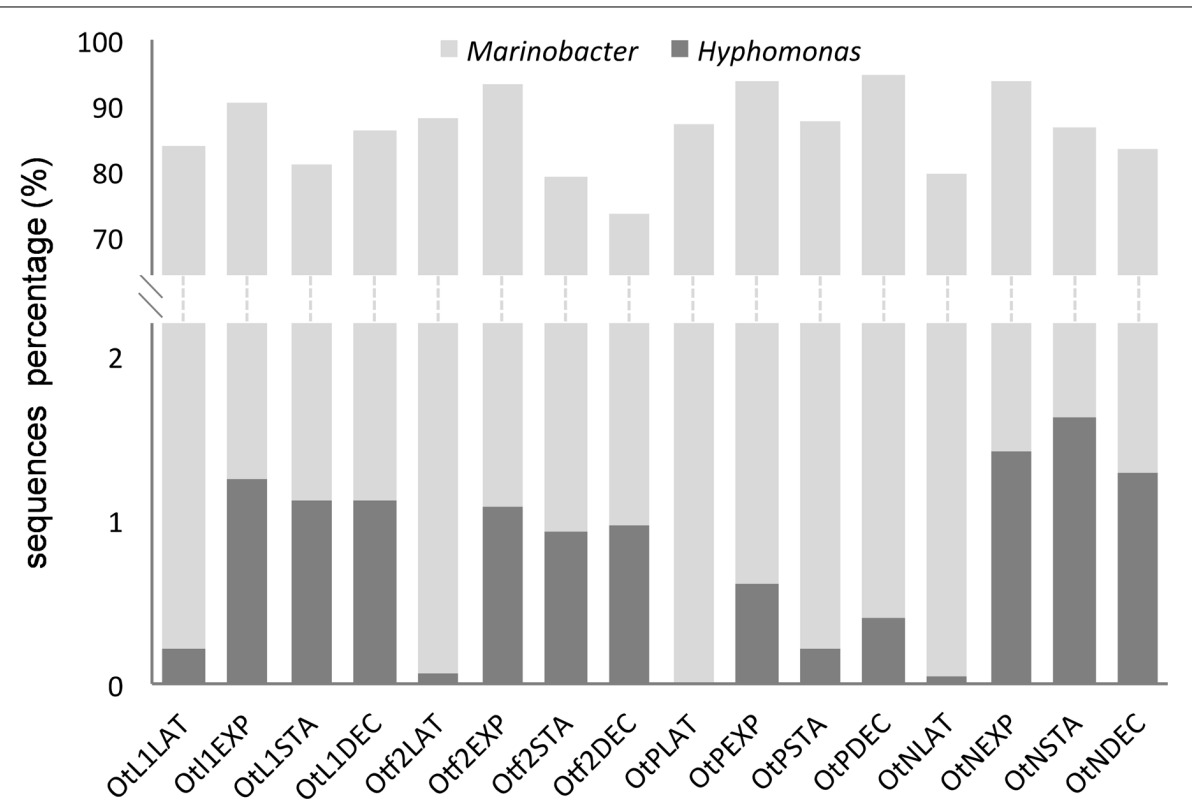

FIGURE 5 | Proportion of Marinobacter and Hyphomonas sequences obtained from total bacterial diversity (IIlumina) analysis in the four experimental conditions and different $\mathbf{O}$. tauri growth phases. Bacterial sequences were obtained from 0 . tauri RCC4221 cultures in the four different media, noted as OtL1, Otf2, OtN (F/2-ESAW 50\%N) and OtP (F/2-ESAW 10\%P), and in the four main growth phases (LAT, latency; EXP, exponential; STA, stationary; and DEC, decline). In each culture condition, an increase in the proportion of Hyphomonas sequences is observed mainly in the exponential, stationary and decline growth phases.

there may be no strict association between one OTU and microalgae, but several closely related OTUs and microalgae, together with Marinobacter spp., like those found in association with dinoflagellates, coccolithophorids, and one diatom (Green et al., 2004, 2015; Amin et al., 2009, 2015). To our knowledge, this is the first report of an association between Marinobacter strains and a green marine microalga from the class Mamiellophyceae.

Marinobacter is the most diversified genus in the Alteromonadaceae (Gauthier et al., 1992; De La Haba et al., 2011) and is commonly found in the oceans worldwide. These bacteria are bacilli with gram-negative walls, halotolerant, with an aerobic metabolism (Gauthier et al., 1992). They use different hydrocarbon sources and are able to perform direct reduction from nitrate to ammonium (known as dissimilatory nitrate reduction) (De La Haba et al., 2011). In our study, the Marinobacter sequences obtained from solid culture medium were closely related to sequences from Marinobacter sp. MOLA20 (AM990796), a bacterial strain isolated from the Gulf of Lion, and to Marinobacter sp. DS1930-III, a bacterial strain which seems to occur as a microbial symbiotic community together with Halomonas sp. and Pelagibaca sp., and in monocultures of the chlorophyte Dunaliella salina (C. Baggesen, unpublished). Several studies have recently described Marinobacter strains related to $M$. algicola species in association with microalgal cultures maintained in laboratory and belonging to a wide range of species diversity across the eukaryotic tree of life (Amin et al., 2009; Kuo and Lin, 2013; Le Chevanton et al., 2013; Green et al., 2015). Indeed, among the seven OTUs identified from 
this study and Marinobacter $16 \mathrm{~S}$ sequences associated with very taxonomically distinct microalgae in the literature (eight OTUs), 14 out of these 15 OTUs cluster all together within the same clade. Members of the genus Marinobacter have been detected in numerous dinoflagellate and coccolithophorid cultures (Alavi et al., 2001; Hold et al., 2001; Amin et al., 2009) which all emerged in M. algicola clade in our study (Figure 4). In addition, a recent analysis of the ectobiotic bacterial diversity associated with the euglenoid Eutreptiella sp. revealed the occurrence of abundant $\gamma$-proteobacteria, specifically Marinobacter (Kuo and Lin, 2013). All of these Marinobacter strains were closely related to M. adhaerens (Kuo and Lin, 2013). We also included two sequences of Marinobacter found associated with different diatoms (one with Pseudo-nitzschia, the other with Thalassiosira) (Grossart et al., 2004; Amin et al., 2015). Interestingly, the two sequences emerged in different clades, the first one with $M$. algicola and our sequences, the second one with $M$. adhaerens (Figure 4).

The presence of Marinobacter species in laboratory cultures raises questions about the possibility of a laboratory artifact. Recent findings argue against this, because Marinobacter species were also recently found in coccolithophorids and dinoflagellates cultures (Green et al., 2015), although at a much lower proportion in diatom cultures cultivated in the same media (Amin et al., 2009). Rather, we have selected the bacterial species that best supports rapid host growth from a diversity of bacteria observed in the O. tauri culture originally isolated (Abby et al., 2014). If Marinobacter tends to show a specific adaptation to coccolithophores and dinoflagellates (Green et al., 2010), it appears that, from our study, it is not limited to these groups and can also be extended to Chlorophyta, another distant lineage.

\section{Other $\gamma$-, $\beta$-, and $\alpha$-Proteobacteria Found in 0 . tauri Cultures}

Contrary to expectations, we did not detect any Roseobacter species although this is the most frequently observed genus in data from surface communities (Morris et al., 2002). However, from both the culture-dependent and Illumina approaches, sequences from the $\alpha$-proteobacteria Hyphomonas sp. were obtained. These sequences are closely related to $H$. johnsonii and to a sequence from a bacterial strain isolated locally (Hyphomonas MOLA116, AM990890). However, we exclude the hypothesis that this bacterial strain was introduced as a contaminant in L1 MOLA medium since this medium was autoclaved and no trace of bacteria was detectable by flow cytometry before use. Interestingly, in a recent study, not only Marinobacter, but also Hyphomonas bacteria were isolated from different isolates of the coastal diatom Pseudo-nitzschia multiseries (Amin et al., 2015) and showed the same phylogenetic position that our sequences in our reconstructions. One sequence belonging to Massilia genus ( $\beta$-proteobacteria), particularly rare in marine environments, was also obtained. Gram-positive bacteria were also frequently found in marine microalgal cultures in laboratory, but were probably the result of contamination from handling rather than from the marine environment (Nicolas et al., 2004).
Flavobacteria 16S rDNA sequences were not found from the solid culture medium approach and quasi-absent $(0.25 \%$ of OTUs) from the Illumina sequencing analysis. Together with $\alpha$ - and $\gamma$-proteobacteria (Morris et al., 2002; Sunagawa et al., 2015), they are the bacteria the most commonly detected in microalgal cultures and phytoplanktonic blooms (Buchan et al., 2014). Almost all culturable and visually distinct bacteria isolated from Chlorella pyrenoidosa, Scenedesmus obliquus, Isochrysis sp., and Nitzschia microcephala microalgal cultures maintained for several years in laboratory belong to the Rhodobacteraceae, Rhizobiaceae, and Erythrobacteraceae families (Schwenk et al., 2014), here again found at very low frequency in O. tauri RCC 4221 cultures $(0.23,0.34$, and $0.04 \%$ of OTUs, respectively).

\section{Dynamics of Bacterial Growth Depends upon the O. tauri RCC4221 Growth Medium}

In the light of results from high throughput Illumina sequencing, the proportion of $\gamma$-proteobacteria and particularly of Marinobacter genus sequences is the largest and encompasses almost all of the bacterial diversity. These different Marinobacter strains were subsequently found by flow cytometry as HNA (high apparent nucleic acid content) or LNA (low apparent nucleic acid content) during algal growth. Classically, HNA bacteria are considered as the most active members of a given community while LNA are regarded as inactive, dead or dormant cells (Gasol et al., 1999; Lebaron et al., 2001, 2002). In addition, in numerous studies, both HNA and LNA are considered to be members of different (Zubkov et al., 2001; Fuchs et al., 2005; Mary et al., 2006) or identical (Flaten et al., 2003; Servais et al., 2003) phylotypes (Andrade et al., 2007). Our dominant bacterial population (i.e., Marinobacter spp.) was found in both HNA and LNA populations but only further experiments using accurate cell sorting and precise identification of these sorted bacteria would confirm that HNA and LNA have identical ribotypes (David Pecqueur, personal communication). The highest O. tauri cell abundance relatively to bacteria was observed during exponential phases where maximal $O$. tauri growth rates were observed. In contrast, the highest bacterial abundance was observed in other phases of the O. tauri growth. One interesting fact which retained our attention is the relatively low abundance of $O$. tauri all along the duration of experiments when cultivated in depleted media such as in $\mathrm{F} / 2$-ESAW $10 \% \mathrm{P}$ medium, demonstrating the importance of phosphorous. By the way, HNA bacteria seem particularly abundant in this particular condition. Globally, $O$. tauri cells growth is higher in L1-MOLA medium than in F/2-ESAW one, and appears highly favored compared to both HNA and LNA bacteria and particularly LNA bacteria growths in this medium. One possible explanation is that additional substances present in natural seawater might promote algal growth. Concerning the modalities of $O$. tauri growth, our results tend to show the importance of phosphorous, while nitrogen limitation doesn't significantly reduce microalgal growth. However, excepted in LD 08:16 photoperiodic condition, there is no clear difference in O. tauri RCC4221 maximal growth rates in exponential phase for cells cultivated in L1-MOLA and 
F/2-ESAW media. We also observed that the bacterial abundance profiles varied with the microalgal culture phases, a higher abundance of bacteria being found in the LAT and DEC phases of O. tauri growth. Some bacteria, in particular $\gamma$-proteobacteria very often live epiphytically on detritic organic particles (DeLong et al., 1993), perhaps explaining the abundance of bacteria when microalgal growth declines.

\section{Possible Roles of Bacteria in Algal Cultures}

The bacteria isolated in this study have probably survived over several years in continuous algal cultures, where only those bacteria capable of growing under nutrient-rich conditions will survive after successive transfers. Some bacterial groups are able to grow rapidly, out-competing other bacteria in enrichment cultures, as seen in Marinobacter species (Handley et al., 2010), when there may be a surplus of organic carbon, or under aerobic to anaerobic conditions (Edwards et al., 2003; Handley et al., 2013). The lifestyle types exhibited by Marinobacter strains such as $M$. aquaeolei have been described as opportunistic, being able to utilize urea and phosphonate as alternative of $\mathrm{N}$ and $\mathrm{P}$ sources, or generalist like Shewanella, Pseudomonas, Vibrio, and Roseobacter (Singer et al., 2011).

In serial endpoint dilution subcultures, only the bacteria associated with the single algal cells used to establish the culture have the opportunity to be present as the culture is grown and transferred. We showed that Marinobacter is present from the beginning of the culture growth. It is almost certain that these bacteria benefit from their coexistence with microalga. Macronutrient concentrations found in algal cultivation media such as F/2-ESAW are about 100-fold higher than those found in coastal marine environments, such as the Bay of Fundy (Guillard and Ryther, 1962; Martin et al., 2001), also favoring bacterial development. Inversely, O. tauri RCC4221 cells probably benefit from the presence of bacteria. Indeed, completely axenic cultures of O. tauri RCC4221 have not so far been possible to maintain, despite the use of antibiotics treatment protocols. Abby et al. (2014) focused on algal cultures maintained without antibiotics for several years (Abby et al., 2014), and found a total of 1425 Marinobacter sequences in an O. tauri RCC4221 culture among over 1400000 sequences (thus, representing 0.10\%). As in the present study, these sequences were all closely related to M. algicola. It is not surprising that Abby et al. (2014) found a greater diversity of different bacterial species present, because cultures were then routinely maintained by subculturing using a larger volume (usually $50 \mu \mathrm{l}$ ) of culture, permitting transfer of a population of bacteria, rather than by dilution through one-cell endpoint dilutions. Over half of all microalgal species require an exogenous supply of vitamin B12 (cobalamin). Among the four B12-dependent enzymes, only one, the methionine synthase, is present in O. tauri genome, and O. tauri was shown to be auxotrophic for vitamin B12 (Helliwell et al., 2011). In addition, a recent study confirmed Ostreococcus to be a thiamine (vitamin B1) auxotroph in laboratory experiments using culture media also containing vitamin B12 (cobalamin) and B7 biotin (Paerl et al., 2015). In this latter study, growth of Ostreococcus was limited following serial subcultures in medium lacking B1. To our knowledge, no such experiment has been conducted to explore the effect of vitamin B7 limitation on O. tauri growth. Bacteria secreting vitamins can stimulate microalgal growth as vitamin-dependent axenic microalgae cannot survive in nutrient-limited medium (Haines and Guillard, 1974; Kurata, 1986; Croft et al., 2005; Grant et al., 2014). Eighteen clones exhibiting a Marinobacter $16 \mathrm{~S}$ sequence closely related to M. adhaerens were obtained from ectobiotic bacteria living with the euglenoid Eutrepsiella sp. (Kuo and Lin, 2013). These bacteria provided vitamin B12 and other growth-enhancing factors for the euglenoid (Kuo and Lin, 2013). However, the growth rate of the diatom Pseudo-nitzschia multiseries was unaffected when co-cultured with Marinobacter in specific experiments where the diatom was previously treated with antibiotics (Amin et al., 2015).

Phytoplankton needs iron in large amounts to support the photosynthetic fixation of carbon. Bacteria from Marinobacter genus can produce siderophores (Vraspir and Butler, 2009) and contribute to iron chelation and internalization (Martinez et al., 2000, 2003). Siderophore (like vibrioferrin) production may be a useful chemotaxonomic marker for algal-associated Marinobacter species (Amin et al., 2009). Our phylogenetic reconstruction (Figure 4) clearly shows the close relationship between our Marinobacter strains and the Marinobacter sp. DG1194 (isolated from an Alexandrium culture), DG1594 (isolated from an Emiliana culture) and DG1597 (isolated from a Coccolithus culture), all shown to produce and uptake vibrioferrin (Amin et al., 2009) $\left(\mathrm{BP}_{\mathrm{NJ}}=65, \mathrm{BP}_{\mathrm{ML}}=56\right.$, Figure 4). In their study, the authors suggested that bacteria may promote algal assimilation of iron (Amin et al., 2009). Bacteria of the Marinobacter genus also seem to stimulate the growth of the dinoflagellate Gymnodinium catenatum (Bolch et al., 2011), and the accumulation of lipids in the commercially important microalgae Nannochloropsis (David Green, personal communication). Although $O$. tauri can be cultured easily in the laboratory, the complete eradication of bacteria is difficult and seems to prevent microalgal growth (unpublished results). This persistence of bacteria in $O$. tauri cultures raises questions regarding the nature of the potential interactions between these microbial populations. Further experiments are needed to investigate the physiological impacts of these newly identified Marinobacter strains in our O. tauri RCC4221 system.

\section{Bacteria Associated with Microalgae in Natural Environments}

Buchan et al. (2014) monitored the succession of bacterial communities associated with diatoms, dinoflagellates, nanoflagellates, and picophytoplankton blooms in a largescale study (Buchan et al., 2014). The main bloom-associated bacterial groups were, in order of abundance, $\alpha$-proteobacteria, Flavobacteriia, and $\gamma$-proteobacteria. In the earliest stages of a bloom, phytoplankton release amino acids, organic acids, carbohydrates, and sugar alcohols which are hypothesized to function as chemoattractants for beneficial bacteria, including bacteria that produce phytoplankton growth-promoting compounds, such as vitamins. At the height of the bloom, 
in response to nutrient-limiting conditions, the release of small molecules by living phytoplankton increases and further stimulates heterotrophic bacterial activity (Buchan et al., 2014). Then, during the waning stage of the bloom, phytoplankton release higher molecular weight macromolecules (polysaccharides, proteins, nucleic acids, lipids, material resulting from cell lysis) (Buchan et al., 2014). In our experiments, we observed a higher proportion of bacteria in the latency (LAT) and decline (DEC) phases of $O$. tauri growth. Some bacteria, in particular $\gamma$-proteobacteria very often live as epiphytes on detritic organic particles (DeLong et al., 1993). This phenomenon could explain the abundance of bacteria particularly when the microalgal growth declines. We also observed a higher bacterial diversity (including mainly Marinobacter, but also Hyphomonas to a lesser extent) during the exponential (EXP), stationary (STA) and decline (DEC) phases of the O. tauri RCC4221 growth, which is congruent with the stimulation of heterotrophic bacterial activity observed by Buchan et al. (2014). Lastly, we have to keep in mind that the type of a given algal-bacterial interaction can also change depending on environmental conditions. In laboratory conditions, the interaction between Scenedesmus obliquus and a non-identified bacterial community evolves from a mutualistic to a competitive interaction in phosphorus-limited conditions (Danger et al., 2007). A mutualistic phase and a pathogenic phase (where bacteria probably killed dinoflagellate cells), were also observed in co-cultures of Dinoroseobacter shibae and Prorocentrum minimum (Wang et al., 2014). These observations highlight the need of further experimentation in co-cultures to assess the complexity of bacterial-algal interactions.

\section{CONCLUSION}

We show that bacterial communities associated with O. tauri RCC4221 laboratory cultures are almost exclusively limited to $\gamma$-proteobacterial strains from the Marinobacter genus, regardless of the growth phases of O. tauri RCC4221 or cultures conditions tested (photoperiod and nutrient depletion). Interestingly, Marinobacter bacteria identified in O. tauri RCC4221 cultures by both culture-dependant and high-throughput sequencing are all closely related to the $M$. algicola clade, regrouping strains known to produce siderophores. Further experiments combining

\section{REFERENCES}

Abby, S. S., Touchon, M., DeJode, A., Grimsley, N., and Piganeau, G. (2014). Bacteria in Ostreococcus tauri cultures - friends, foes or hitchhikers? Front. Microbiol. 5:505. doi: 10.3389/fmicb.2014.00505

Alavi, M., Miller, T., Erlandson, K., Schneider, R., and Belas, R. (2001). Bacterial community associated with Pfiesteria-like dinoflagellate cultures. Environ. Microbiol. 3, 380-396. doi: 10.1046/j.1462-2920.2001. 00207.x

Amin, S., Green, D. H., Al Waheeb, D., Gärdes, A., and Carrano, C. (2012a). Iron transport in the genus Marinobacter. Biometals 25, 135-147. doi: 10.1007/s10534-011-9491-9

Amin, S. A., Green, D. H., Hart, M. C., Küpper, F. C., Sunda, W. G., and Carrano, C. J. (2009). Photolysis of iron-siderophore chelates promotes bacterial-algal mutualism. Proc. Natl. Acad. Sci. U.S.A. 106, 17071-17076. doi: 10.1073/pnas.0905512106 co-cultures with vitamins or nutrient-limiting conditions should provide additional insights in these green algal-bacterial interactions.

\section{AUTHOR CONTRIBUTIONS}

JL performed experimental approaches, figures, and participated to the writing of the manuscript. RL analyzed high throughput Illumina raw data and participated to the writing of the manuscript. MK performed endpoint dilution experiments and participated to the writing of the manuscript. NG, HM, and GP helped to design the experiments and actively participated to the writing of the manuscript. SS-F conceived the study, participated to the experiments, performed phylogenetic analyses, and wrote the manuscript.

\section{FUNDING}

JL was supported by Sorbonne Universités, SATS-SU, “ANR11-IDEX-0004-02." This work was funded by the PHYTNESS project “ANR-13-JSV6-0005.”

\section{ACKNOWLEDGMENTS}

We would like to thank David Pecqueur and Christophe Salmeron from the Cytometry platform (Observatoire Océanologique, Banyuls-sur-mer) and the Genomics of Phytoplankton group for stimulating discussions and technical help.

\section{SUPPLEMENTARY MATERIAL}

The Supplementary Material for this article can be found online at: http://journal.frontiersin.org/article/10.3389/fmicb. 2016.01414

TABLE S1 | Composition of L1-MOLA (Guillard and Hargraves, 1993) and F/2-ESAW (Harrison et al., 1980) media. (nd, not determined).

Amin, S. A., Hmelo, L. R., van Tol, H. M., Durham, B. P., Carlson, L. T., Heal, K. R., et al. (2015). Interaction and signalling between a cosmopolitan phytoplankton and associated bacteria. Nature 522, 98-101. doi: 10.1038/nature 14488

Amin, S. A., Parker, M. S., and Armbrust, E. V. (2012b). Interactions between diatoms and bacteria. Microbiol. Mol. Biol. Rev. 76, 667-684. doi: 10.1128/MMBR.00007-12

Andrade, L., Gonzalez, A. M., Rezende, C. E., Suzuki, M., Valentin, J. L., and Paranhos, R. (2007). Distribution of HNA and LNA bacterial groups in the southwest Atlantic Ocean. Braz. J. Microbiol. 38, 330-336. doi: 10.1590/S151783822007000200028

Bell, W., and Mitchell, R. (1972). Chemotactic and growth responses of marine bacteria to algal extracellular products. Biol. Bull. 143, 265-277. doi: $10.2307 / 1540052$

Bižić-Ionescu, M., Zeder, M., Ionescu, D., Orlić, S., Fuchs, B. M., Grossart, H. P., et al. (2015). Comparison of bacterial communities on limnic versus 
coastal marine particles reveals profound differences in colonization. Environ. Microbiol. 17, 3500-3514. doi: 10.1111/1462-2920.12466

Blanc-Mathieu, R., Verhelst, B., Derelle, E., Rombauts, S., Bouget, F.-Y., Carré, I., et al. (2014). An improved genome of the model marine alga Ostreococcus tauri unfolds by assessing Illumina de novo assemblies. BMC Genomics 15:1103. doi: 10.1186/1471-2164-15-1103

Bolch, C. J. S., Subramanian, T. A., and Green, D. H. (2011). The toxic dinoflagellate Gymnodinium catenatum (Dinophyceae) requires marine bacteria for growth J. Phycol. 47, 1009-1022. doi: 10.1111/j.1529-8817.2011.01043.x

Bratbak, G., and Thingstad, T. F. (1985). Phytoplankton-bacteria interactions: an apparent paradox? Analysis of a model system with both competition and commensalism. Mar. Ecol. Prog. Ser. 25, 23-30.

Buchan, A., LeCleir, G. R., Gulvik, C. A., and González, J. M. (2014). Master recyclers: features and functions of bacteria associated with phytoplankton blooms. Nat. Rev. Microbiol. 348, 1261359. doi: 10.1038/nrmicro3326

Caporaso, J. G., Kuczynski, J., Stombaugh, J., Bittinger, K., Bushman, F. D., Costello, E. K., et al. (2010). QIIME allows analysis of highthroughput community sequencing data. Nat. Methods 7, 335-336. doi: 10.1038/nmeth.f.303

Cole, J. (1982). Interactions between bacteria and algae in aquatic ecosystmes. Annu. Rev. Ecol. Syst. 13, 291-314. doi: 10.1146/annurev.es.13.110182.001451

Courties, C., Vaquer, A., Troussellier, M., Lautier, J., Chrétiennot-Dinet, M.-J., Neveux, J., et al. (1994). Smallest eukaryotic organism. Nature 370, 255. doi: $10.1038 / 370255 \mathrm{a} 0$

Croft, M. T., Lawrence, A. D., Raux-Deery, E., Warren, M. J., and Smith, A. G. (2005). Algae acquire vitamin B-12 through a symbiotic relationship with bacteria. Nature 438, 90-93. doi: 10.1038/nature04056

Danger, M., Oumarou, C., Benest, D., and Lacroix, G. (2007). Bacteria can control stoichiometry and nutrient limitation of phytoplankton. Funct. Ecol. 21, 202210. doi: 10.1111/j.1365-2435.2006.01222.x

De La Haba, R., Sánchez-Porro, C., Marquez, M., and Ventosa, A. (2011). "Taxonomy of Halophiles," in Extremophiles Handbook, eds K. Horikoshi, G. Antranikian, A. T. Bull, F. T. Robb, and K. O. Stetter (Tokyo: Springer), 255-265.

de Vargas, C., Audic, S., Henry, N., Decelle, J., Mahé, F., Logares, R., et al. (2015). Eukaryotic plankton diversity in the sunlit ocean. Science 348, 6237. doi: $10.1126 /$ science. 1261605

de-Bashan, L., Hernandez, J.-P., Morey, T., and Bashan, Y. (2004). Microalgae growth-promoting bacteria as "helpers" for microalgae: a novel approach for removing ammonium and phosphorus from municipal wastewater. Water Res. 38, 466-474. doi: 10.1016/j.watres.2003.09.022

de-Bashan, L. E., Antoun, H., and Bashan, Y. (2008). Involvement of indole-3acetic-acid produced by the growth-promoting bacterium Azospirillum spp. in promoting growth of Chlorella vulgaris. J. Phycol. 44, 938-947. doi: 10.1111/j.1529-8817.2008.00533.x

DeLong, E. F., Franks, D. G., and Alldredge, A. L. (1993). Phylogenetic diversity of aggregate-attached vs. free-living marine bacterial assemblages. Limnol. Oceanogr. 38, 924-934. doi: 10.4319/lo.1993.38.5.0924

Derelle, E., Ferraz, C., Rombauts, S., Rouze, P., Worden, A. Z., Robbens, S., et al. (2006). Genome analysis of the smallest free-living eukaryote Ostreococcus tauri unveils many unique features. Proc. Natl. Acad. Sci. U.S.A. 103, 11647-11652. doi: 10.1073/pnas.0604795103

Edwards, K. J., Rogers, D. R., Wirsen, C. O., and McCollom, T. M. (2003). Isolation and characterization of novel psychrophilic, neutrophilic, $\mathrm{Fe}$ oxidizing, chemolithoautotrophic alpha- and gamma-proteobacteria from the deep sea. Appl. Environ. Microbiol. 69, 2906-2913.

Eigemann, F., Hilt, S., Salka, I., and Grossart, H.-P. (2013). Bacterial community composition associated with freshwater algae: species specificity vs. dependency on environmental conditions and source community. FEMS Microbiol. Ecol. 83, 650-663. doi: 10.1111/1574-6941.12022

Flaten, G. A. F., Castberg, T., Tanaka, T., and Thingstad, T. F. (2003). Interpretation of nutrient-enrichment bioassays by looking at sub-populations in a marine bacterial community. Aquat. Microb. Ecol. 33, 11-18. doi: 10.3354/ame 033011

Fouilland, E., and Mostajir, B. (2010). Revisited phytoplanktonic carbon dependency of heterotrophic bacteria infreshwaters, transitional, coastal and oceanicwaters. FEMS Microbiol. Ecol. 73, 419-429. doi: 10.1111/j.15746941.2010.00896.x
Fouilland, E., Mostajir, B., Torréton, J.-P., Bouvy, M., Got, P., Le Floc'h, E., et al. (2013). Microbial carbon and nitrogen production under experimental conditions combining warming with increased ultraviolet- $B$ radiation in Mediterranean coastal waters. J. Exp. Mar. Biol. Ecol. 439, 47-53. doi: 10.1016/j.jembe.2012.10.014

Fuchs, B. M., Woebken, D., Zubkov, M. V., Burkill, P., and Amann, R. (2005). Molecular identification of picoplankton populations in contrasting waters of the Arabian Sea. Aquat. Microb. Ecol. 39, 145-157. doi: 10.3354/ame039145

Fuhrman, J. A., Ammerman, J. W., and Azam, F. (1980). Bacterioplankton in the Coastal Euphotic Zone: distribution, activity and possible relationships with phytoplankton. Mar. Biol. 60, 201-207. doi: 10.1111/1574-6968.12490

Fukami, K., Nishijima, T., and Ishida, Y. (1997). Stimulative and inhibitory effects of bacteria on the growth of microalgae. Hydrobiologia 358, 185-191. doi: 10.1023/A:1003141104693

Gasol, J. M., Zweifel, U.-L., Peters, F., Furhman, J. A., and Hagström, Å. (1999). Significance of size and nucleic acid content heterogeneity as assessed by flow cytometry in natural planktonic bacteria. Appl. Environ. Microbiol. 65, 4475-4483.

Gauthier, M., Lafay, B., Christen, R., Fernandez, L., Acquaviva, M., Bonin, P., et al. (1992). Marinobacter hydrocarbonoclasticus gen. nov., sp. nov., a new, extremely halotolerant, hydrocarbon-degrading marine bacterium. Int. J. Syst. Bacteriol. 42, 568-576. doi: 10.1099/00207713-42-4-568

Glöckner, F., Fuchs, B., and Amann, R. (1999). Bacterioplankton compositions of lakes and oceans: a first comparison based on fluorescence in situ hybridization. Appl. Environ. Microbiol. 65, 3721-3726.

Godon, J. J., Zumstein, E., Dabert, P., Habouzit, F., and Moletta, R. (1997). Molecular microbial diversity of an anaerobic digestor as determined by smallsubunit rDNA sequence analysis. Appl. Environ. Microbiol. 63, 2802-2813.

Gonzalez, J. M., Simo, R., Massana, R., Covert, J. S., Casamayor, E. O., Pedros-Alio, C., et al. (2000). Bacterial community structure associated with a dimethylsulfoniopropionate-producing North Atlantic algal Bloom. Appl. Environ. Microbiol. 66, 4237-4246. doi: 10.1128/AEM.66.10.4237-4246.2000

Gonzalez, L. E., and Bashan, Y. (2000). Increased growth of the microalga chlorella vulgaris when coimmobilized and cocultured in alginate beads with the plantgrowth-promoting bacterium Azospirillum brasilense. Appl. Environ. Microbiol. 66, 1527-1531. doi: 10.1128/AEM.66.4.1527-1531.2000

Grant, M. A., Kazamia, E., Cicuta, P., and Smith, A. G. (2014). Direct exchange of vitamin B12 is demonstrated by modelling the growth dynamics of algalbacterial cocultures. ISME J. 8, 1418-1427. doi: 10.1038/ismej.2014.9

Green, D. H., Echavarri-Bravo, V., Brennan, D., and Hart, M. C. (2015). Bacterial diversity associated with the coccolithophorid algae Emiliania huxleyi and Coccolithus pelagicus f. braarudii. Biomed Res. Int. 2015:194540. doi: $10.1155 / 2015 / 194540$

Green, D. H., Hart, M. C., Blackburn, S. I., and Bolch, C. J. S. (2010). Bacterial diversity of Gymnodinium catenatum and its relationship to dinoflagellate toxicity. Aquat. Microb. Ecol. 61, 73-87. doi: 10.3354/ame01437

Green, D. H., Llewellyn, L. E., Negri, A. P., Blackburn, S. I., and Bolch, C. J. S. (2004). Phylogenetic and functional diversity of the cultivable bacterial community associated with the paralytic shellfish poisoning dinoflagellate Gymnodinium catenatum. FEMS Microbiol. Ecol. 47, 345-357. doi: 10.1016/S0168-6496(03)00298-8

Grossart, H.-P., Levold, F., Allgaier, M., Simon, M., and Brinkhoff, T. (2005). Marine diatom species harbour distinct bacterial communities. Environ. Microbiol. 7, 860-873. doi: 10.1111/j.1462-2920.2005.00759.x

Grossart, H. P., Schlingloff, A., Bernhard, M., Simon, M., and Brinkhoff, T. (2004). Antagonistic activity of bacteria isolated from organic aggregates of the German Wadden Sea. FEMS Microbiol. Ecol. 47, 387-396. doi: 10.1016/S01686496(03)00305-2

Guillard, R., and Ryther, J. (1962). Studies of marine planktonic diatoms. I. Cyclotella nana Hustedt, and Detonula confervacea (Cleve) Gran. Can. J. Microbiol. 8, 229-239.

Guillard, R. R. L., and Hargraves, P. E. (1993). Stichochrysis immobilis is a diatom, not a chrysophyte. Phycologia 32, 234-236. doi: 10.2216/i0031-8884-32-3-234.1

Haines, K. C., and Guillard, R. L. (1974). Growth of vitamin B12 requiring marine diatoms in mixed laboratory cultures with vitamin B12 producing marine bacteria. J. Phycol. 10, 245-252. doi: 10.1111/j.1529-8817.1974.tb02709.x

Handley, K. M., Boothman, C., McBeth, J., Charnock, J. M., Wincott, P. L., Vaughan, D. J., et al. (2013). Effect of microbially mediated iron redox 
transformations on arsenic solid-phase associations in a high-iron, arsenicrich hydrothermal sediment. Geochim. Cosmochim. Acta 102, 124-142. doi: 10.1016/j.gca.2012.10.024

Handley, K. M., Boothman, C., Mills, R. A., Pancost, R. D., and Lloyd, J. R. (2010). Functional diversity of bacteria in a ferruginous hydrothermal sediment. ISME J. 4, 1193-1205. doi: 10.1038/ismej.2010.38

Harrison, P. J., Waters, R. E., and Taylor, F. J. R. (1980). A broad spectrum artificial seawater medium for coastral and open ocean phytoplankton. J. Phycol. 16, 28-35. doi: 10.1111/j.1529-8817.1980.tb00724.x

Helliwell, K. E., Wheeler, G. L., Leptos, K. C., Goldstein, R. E., and Smith, A. G. (2011). Insights into the evolution of vitamin B12 auxotrophy from sequenced algal genomes. Mol. Biol. Evol. 28, 2921-2933. doi: 10.1093/molbev/msr124

Herlemann, D. P., Labrenz, M., Jürgens, K., Bertilsson, S., Waniek, J. J., and Andersson, A. F. (2011). Transitions in bacterial communities along the $2000 \mathrm{~km}$ salinity gradient of the Baltic Sea. ISME J. 5, 1571-1579. doi: 10.1038/ismej.2011.41

Hold, G. L., Smith, E. A., Rappé, M. S., Maas, E. W., Moore, E. R. B., Stroempl, C., et al. (2001). Characterisation of bacterial communities associated with toxic and non-toxic dinoflagellates: Alexandrium spp. and Scrippsiella trochoidea. FEMS Microbiol. Ecol. 37, 161-173. doi: 10.1111/j.1574-6941.2001.tb00864.x

Jasti, S., Sieracki, M. E., Poulton, N. J., Giewat, M. W., and Rooney-Varga, J. N. (2005). Phylogenetic diversity and specificity of bacteria closely associated with Alexandrium spp. and other Phytoplankton. Appl. Environ. Microbiol. 71, 3483-3494. doi: 10.1128/AEM.71.7.3483-3494.2005

Kawafune, K., Hongoh, Y., Hamaji, T., and Nozaki, H. (2012). Molecular identification of rickettsial endosymbionts in the nonphagotrophic volvocalean green algae. PLoS ONE 7:e31749. doi: 10.1371/journal.pone.0031749

Kazamia, E., Riseley, A. S., Howe, C. J., and Smith, A. G. (2014). An engineered community approach for industrial cultivation of microalgae. Ind. Biotechnol. 10, 184-190. doi: 10.1089/ind.2013.0041

Krasovec, M., Eyre-Walker, A., Grimsley, N., Salmeron, C., Pecqueur, D., Piganeau, G., et al. (2016). Fitness effects of spontaneous mutations in picoeukaryotic marine green algae. G3 (Bethesda) 6, 2063-2071. doi: 10.1534/g3.116.029769

Kuo, R. C., and Lin, S. (2013). Ectobiotic and endobiotic bacteria associated with Eutreptiella sp. Isolated from Long Island Sound. Protist 164, 60-74. doi: 10.1016/j.protis.2012.08.004

Kurata, A. (1986). "Blooms of Uroglena americana in relation to concentrations of B group vitamins," in Chrysophytes: Aspects and Problems, eds J. Kristiansen and R. A. Andersen (Cambridge: Cambridge University Press), 185-196.

Le Chevanton, M., Garnier, M., Bougaran, G., Schreiber, N., Lukomska, E., Bérard, J.-B., et al. (2013). Screening and selection of growth-promoting bacteria for Dunaliella cultures. Algal Res. 2, 212-222. doi: 10.1016/j.algal.2013. 05.003

Lebaron, P., Servais, P., Agongué, H., Courties, C., and Joux, F. (2001). Does the high nucleic acid content of individual bacterial cells allow us to discriminate between active cells and inactive cells in aquatic systems? Appl. Environ. Microbiol. 67, 1775-1782. doi: 10.1128/AEM.67.4.1775-1782.2001

Lebaron, P., Servais, P., Baudoux, A., Bourrain, M., Courties, C., and Parthuisot, N. (2002). Variations of bacterial-specific activity with cell size and nucleic acid content assessed by flow cytometry. Aquat. Microbial. Ecol. 28, 131-140. doi: 10.3354/ame028131

Levasseur, M., Thompson, P. A., and Harrison, P. J. (1993). Physiological acclimation of marine phytoplankton to different nitrogen sources. J. Phycol. 29, 587-595. doi: 10.1111/j.0022-3646.1993.00587.x

Marie, D., Partensky, F., Jacquet, S., and Vaulot, D. (1997). Enumeration and cell cycle analysis of natural populations of marine picoplankton by flow cytometry using the nucleic acid strain SYBR Green I. Appl. Environ. Microbiol. 63, $186-193$.

Martin, J. L., LeGresley, M. M., and Strain, P. M. (2001). Phytoplankton monitoring in the western Isles region of the Bay of Fundy during 1997-98. Can. Tech. Rep. Fish. Aquat. Sci. 2349, 85.

Martinez, J., Carter-Franklin, J., Mann, E., Martin, J., Haygood, M., and Butler, A. (2003). Structure and membrane affinity of a suite of amphiphilic siderophores produced by a marine bacterium. Proc. Natl. Acad. Sci. U.S.A. 100, 3754-3759. doi: $10.1073 /$ pnas. 0637444100
Martinez, J., Zhang, G., Holt, P., Jung, H.-T., Carrano, C., Haygood, M., et al. (2000). Self-assembling amphiphilic siderophores from marine bacteria. Science 287, 1245-1247. doi: 10.1126/science.287.5456.1245

Mary, I., Heywood, J. L., Fuchs, B. M., Amann, R., Burkill, P. H., Tarran, G. A., et al. (2006). SAR11 dominance among metabolically active low nucleic acid bacterioplankton in surface waters along an Atlantic meridional transect. Aquat. Microb. Ecol. 45, 107-113. doi: 10.3354/ame045107

Mayali, X., and Azam, F. (2004). Algicidal bacteria in the sea and their impact on algal Blooms. J. Eukaryot. Microbiol. 51, 139-144. doi: 10.1111/j.15507408.2004.tb00538.x

Middelboe, M., Søndergaard, M., Letarte, Y., and Borch, N. (1995). Attached and free-living bacteria: production and polymer hydrolysis during a diatom bloom. Microb. Ecol. 29, 231-248. doi: 10.1007/BF00164887

Mishamandani, S., Gutierrez, T., Berry, D., and Aitken, M. D. (2016). Response of the bacterial community associated with a cosmopolitan marine diatom to crude oil shows a preference for the biodegradation of aromatic hydrocarbons. Environ. Microbiol. 18, 1817-1833. doi: 10.1111/1462-2920. 12988

Morris, R. M., Rappé, M. S., Connon, S. A., Vergin, K. L., Siebold, W. A., Carlson, C. A., et al. (2002). SAR11 clade dominate ocean surface bacterioplankton communities. Nature 420, 806. doi: 10.1038/nature01240

Nicolas, J.-L., Corre, S., and Cochard, J.-C. (2004). Bacterial population association with phytoplankton cultured in a bivalve hatchery. Microb. Ecol. 48, 400-413. doi: 10.1007/s00248-003-2031-6

O'Kelly, C., Sieracki, M., Thier, A., and Ic, H. (2003). A transient bloom of Ostreococcus (Chlorophyta, Prasinophyceae) in West Neck Bay, Long Island, New York. J. Phycol. 39, 850-854.

Paerl, R. W., Bertrand, E. M., Allen, A. E., Palenik, B., and Azam, F. (2015). Vitamin B1 ecophysiology of marine picoeukaryotic algae: strain-specific differences and a new role for bacteria in vitamin cycling. Limnol. Oceanogr. 60, 215-228. doi: 10.1002/lno.10009

Rooney-Varga, J. N., Giewat, M. W., Savin, M. C., Sood, S., LeGresley, M., and Martin, J. L. (2005). Links between phytoplankton and bacterial community dynamics in a coastal marine environment. Microb. Ecol. 49, 163-175. doi: 10.1007/s00248-003-1057-0

Sanchez-Ferandin, S., Leroy, F., Bouget, F.-Y., and Joux, F. (2013). A new, sensitive marine microalgal recombinant biosensor using luminescence monitoring for the toxicity testing of antifouling biocides. Appl. Environ. Microbiol. 79, 631638. doi: 10.1128/AEM.02688-12

Sapp, M., Schwaderer, A. S., Wiltshire, K. H., Hoppe, H.-G., Gerdts, G., and Wichels, A. (2007a). Species-specific bacterial communities in the phycosphere of microalgae? Microb Ecol. 53, 683-699. doi: 10.1007/s00248-006-9162-5

Sapp, M., Wichels, A., and Gerdts, G. (2007b). Impacts of cultivation of marine diatoms on the associated bacterial community. Appl. Environ. Microbiol. 73, 3117-3120. doi: 10.1128/AEM.02274-06

Schäfer, H., Abbas, B., Witte, H., and Muyzer, G. (2002). Genetic diversity of 'satellite' bacteria present in cultures of marine diatoms. FEMS Microbiol. Ecol. 42, 25-35. doi: 10.1111/j.1574-6941.2002.tb00992.x

Schwenk, D., Nohynek, L., and Rischer, H. (2014). Algae-bacteria association inferred by $16 \mathrm{~S}$ rDNA similarity in established microalgae cultures. Microbiologyopen 3, 356-368. doi: 10.1002/mbo3.175

Servais, P., Casamayor, E. O., Courties, C., Catalla, P., Parthuisot, N., and Lebaron, P. (2003). Activity and diversity of bacterial cells with high and low nucleic acid content. Aquat. Microb. Ecol. 33, 41-51. doi: 10.3354/ame033041

Shapiro, L. P., Johnson, M. D., Berardesco, G., and Nealson, K. H. (1998). The use of denaturing gradient electrophoresis (DGGE) to identify bacteria living within the phycosphere of marine phytoplankton. J. Phycol. 34(Suppl.), 66.

Singer, E., Webb, E., Nelson, W., Heidelberg, J., Ivanova, N., Pati, A., et al. (2011). Genomic potential of Marinobacter aquaeolei, a biogeochemical “opportunitroph". Appl. Environ. Microbiol. 77, 2763-2771. doi: 10.1128/AEM.01866-10

Smith, D. C., Steward, G. F., Long, R. A., and Azam, F. (1995). Bacterial mediation of carbon fluxes during a diatom bloom in a mesocosm. Deep Sea Res. II 42, 75-97. doi: 10.1016/0967-0645(95)00005-B

Sunagawa, S., Coelho, L. P., Chaffron, S., Kultima, J. R., Labadie, K., Salazar, G., et al. (2015). Structure and function of the global ocean microbiome. Science 348, 1261359. doi: 10.1126/science.1261359 
Tamura, K., Stecher, G., Peterson, D., Filipski, A., and Kumar, S. (2013). MEGA6 : molecular evolutionary genetics analysis version 6.0. Mol. Biol. Evol. 30, 27252729. doi: 10.1093/molbev/mst197

Taylor, J. (1962). The estimation of numbers of bacteria by tenfold dilution series. J. Appl. Bacteriol. 25, 54-61. doi: 10.1111/j.1365-2672.1962.tb01119.x

Thompson, J., Higgins, D., and Gibson, T. (1994). CLUSTAL W: improving the sensitivity of progressive multiple sequence alignment through sequence weighting, position-specific gap penalties and weight matrix choice. Nucleic Acids Res. 22, 4673-4680. doi: 10.1093/nar/22.22.4673

Vraspir, J., and Butler, A. (2009). Chemistry of marine ligands and siderophores. Annu. Rev. Mar. Sci. 1, 43-63. doi: 10.1146/annurev.marine.010908. 163712

Wang, H., Tomasch, J., Jarek, M., and Wagner-Döbler, I. (2014). A dualspecies co-cultivation system to study the interactions between Roseobacters and dinoflagellates. Front. Microbiol. 5:311. doi: 10.3389/fmicb.2014. 00311

Winnepenninckx, B., Backeljau, T., and De Wachter, R. (1993). Extraction of high molecular weight DNA from molluscs. Trends Genet. 9, 407. doi: 10.1016/01689525(93)90102-N
Zhang, S., Sun, G. X., Yin, X. X., Rensing, C., and Yg, Z. (2013). Biomethylation and volatilization of arsenic by the marine microalgae Ostreococcus tauri. Chemosphere 93, 47-53. doi: 10.1016/j.chemosphere.2013.04.063

Zubkov, M. V., Fuchs, B. M., Burkill, P. H., and Amann, R. (2001). Comparison of cellular and biomass specific activities of dominant bacterioplankton groups in stratified waters of the Celtic Sea. Appl. Environ. Microbiol. 67, 5210-5218. doi: 10.1128/AEM.67.11.5210-5218.2001

Conflict of Interest Statement: The authors declare that the research was conducted in the absence of any commercial or financial relationships that could be construed as a potential conflict of interest.

Copyright (c) 2016 Lupette, Lami, Krasovec, Grimsley, Moreau, Piganeau and Sanchez-Ferandin. This is an open-access article distributed under the terms of the Creative Commons Attribution License (CC BY). The use, distribution or reproduction in other forums is permitted, provided the original author(s) or licensor are credited and that the original publication in this journal is cited, in accordance with accepted academic practice. No use, distribution or reproduction is permitted which does not comply with these terms. 